\title{
PEMBAHARUAN REGULASI JASA KONSTRUKSI DALAM UPAYA MEWUJUDKAN STRUKTUR USAHA YANG KOKOH, ANDAL, BERDAYA SAING TINGGI DAN PEKERJAAN KONSTRUKSI YANG BERKUALITAS
}

(Construction Services Regulation Reform in Efforts to Realize a Solid, Reliably, Highly Competitive and Quality of Construction Work)

\author{
Ade Irawan Taufik \\ Badan Pembinaan Hukum Nasional Kementerian Hukum dan Hak Asasi Manusia RI \\ Jl. Mayjen Soetoyo, Cililitan, Jakarta Timur \\ e-mail: ade.taufik@bphn.go.id / ade_irawancute@yahoo.com
}

Naskah diterima: 11 Mei 2012; revisi: 02 Juli 2012; disetujui: 19 Juli 2012

\begin{abstract}
Abstrak
Jasa konstruksi mempunyai peranan penting dan strategis dalam menghasilkan prasarana dan sarana yang berfungsi mendukung pertumbuhan dan perkembangan berbagai bidang. Dalam mendukung tujuan pembangunan tersebut, pengembangan jasa konstruksi diarahkan untuk memiliki daya saing dan struktur usaha kokoh yang tercermin dengan terwujudnya kemitraan yang sinergis antar penyedia jasa, baik yang berskala besar, menengah, dan kecil, maupun yang berkualifikasi umum, spesialis, dan terampil. Permasalahan yang diteliti adalah bagaimana kondisi pengaturan jasa konstruksi saat ini dan bagaimana arah pembaharuan regulasi konstruksi di masa depan dalam mewujudkan struktur usaha yang kokoh, andal, berdaya saing tinggi dan hasil pekerjaan konstruksi yang berkulitas. Dengan menggunakan metode penelitian normatif empirik dihasilkan dapat diketahui bahwa kondisi jasa usaha konstruksi pada saat ini belum mewujudkan struktur usaha jasa konstruksi yang kokoh, andal, berdaya saing tinggi. Regulasi jasa konstruksi saat ini belum memadai sehingga perlu segera dilakukan pembaharuan regulasi mengenai hal ini.
\end{abstract}

Kata kunci: regulasi, jasa konstruksi, kemitraan, daya saing

Abstract
Construction services have an important and strategic role in producing a functioning infrastructure and facilities to support growth and development of various fields. In support of these development objectives, development of construction services geared to be competitive and have a solid business structure that is reflected by the establishment of a synergistic partnership between service providers, both large-scale, medium, and small, as well as a public, specialists, and skilled service providers. The problems studied are the condition of the current regulation of construction services; and how to reform the regulation of construction in the future in creating a solid business structure, reliable and highly competitive and qualified construction work outcome. By using normative empirical research method, can be seen that the condition of the construction business services nowadays have not creating a solid, reliable and highly competitive business structure. Regulation of construction services is currently inadequate to treat the condition so it need an immediate regulatory reform.

Keywords: regulation, constructions services, partnership, competition 


\section{A. Pendahuluan}

Konstruksi merupakan sektor perekonomian yang sangat penting untuk menghasilkan suatu produk bangunan, baik dalam fungsinya sebagai infrastruktur ${ }^{1}$ maupun properti, serta penyumbang Produk Domestik Bruto (PDB) yang signifikan. Keluaran (output) dari sektor ini sangat penting bagi pembangunan sosial ekonomi bangsa dan merupakan masukan (input) bagi sektor-sektor perekonomian lainnya. Sektor konstruksi juga berperan penting dalam pembentukan Gross Fixed Capital Formation $(G F C F)^{2}$. Sebagai aset fisik, infrastruktur berfungsi memberi layanan bagi berbagai aktivitas sosial ekonomi masyarakat dan menjadi social overhead capital $^{3}$ bagi pembangunan suatu bangsa. Selanjutnya, produk sektor konstruksi seperti jaringan jalan, jembatan, bendungan dan jaringan irigasi, perumahan dan permukiman, gedung tempat tinggal dan perdagangan, bandar udara dan pelabuhan menjadi pembentuk lingkungan terbangun (built environment). ${ }^{4}$

Dalam pembangunan nasional, jasa konstruksimempunyaiperanan penting dan strategis mengingat jasa konstruksi menghasilkan produk akhir berupa bangunan atau bentuk fisik lainnya, baik yang berupa prasarana maupun sarana yang berfungsi mendukung pertumbuhan dan perkembangan berbagai bidang, terutama bidang ekonomi, sosial, dan budaya. Jasa konstruksi nasional diharapkan semakin mampu mengembangkan perannya dalam pembangunan nasional melalui peningkatan keandalan yang didukung oleh struktur usaha yang kokoh dan mampu mewujudkan hasil pekerjaan konstruksi yang berkualitas. ${ }^{5}$ Perhatian terhadap pengembangan jasa konstruksi sebagai salah satu sektor dalam mewujudkan tujuan pembangunan, sebagaimana tertuang dalam

\footnotetext{
Infrastruktur merupakan prasarana atau segala sesuatu yang merupakan penunjang terselenggaranya suatu proses (usaha, pembangunan, proyek, dan sebagainya), Tim Penyusun Kamus Pusat Pembinaan dan Pengembangan Bahasa Departemen Pendidikan dan Kebudayaan, Kamus Besar Bahasa Indonesia, (Jakarta: Balai Pustaka, 1990), hlm. 331 dan 699. Di dalam Black's Law Dictionary, infrastruktur atau infrastructure diartikan sebagai "the underlying framework of a system; esp., public services and facilities (such as highways, schools, bridges, sewers, and water systems) needed to support commerce as well as economic and residential development)", Bryan A. Garner (Ed.), Black's Law Dictionary $9^{\text {th }}$ Edition, (St. Paul Minnesota, USA: Thomas Reuters, 2010), hlm. 668. Infrastruktur dalam konteks pembangunan fisik diartikan sebagai sebagai komponen-komponen tributari (yang sengaja dibangun, manmade) untuk mendukung/mempermudah masyarakat terhadap akses mobilitas manusia, barang dan jasa, pemanfaatan dan pengendalian sumber daya air, akses dan mobilitas sumber daya energi, akses komunikasi, serta akses atas sarana dan prasarana permukiman/tempat tinggal (sumber: Badan Pembinaan Konstruksi Kementerian Pekerjaan Umum, Glossary Sumber Daya Investasi, http://pusbinsdi.net/glossary. php?lagi=0, diakses tanggal 10 Juni 2012).

2 Gross Fixed Capital Formation (GFCF) meliputi pekerjaan tanah (pagar, selokan, saluran air, dan sebagainya); pabrik, mesin, dan pembelian peralatan, dan pembangunan jalan, kereta api, dan sejenisnya, termasuk sekolah, kantor, rumah sakit, tempat tinggal perumahan swasta, dan bangunan komersial dan industri (sumber: http:// data.worldbank.org/indicator/NE.GDI.FTOT.CD, diakses tanggal 01 Juli 2012).

3 Social Overhead Capital merupakan barang-barang modal yang menjadi dasar atau sarana penting bagi keperluan masyarakat yang secara tidak langsung bermanfaat dalam usaha meningkatkan produksi, seperti perumahan, sekolah, rumah sakit dan lain-lain.

4 Tim Penyusun Buku Konstruksi Indonesia 2011, Konstruksi Indonesia 2011, Penyelenggaraan Infrastruktur Berkelanjutan, Inovasi Investasi dan Dukungan Sektor Konstruksi Indonesia, (Jakarta: Kementerian Pekerjaan Umum, 2011), hlm. 6.

5 Lihat Penjelasan Umum Undang-Undang Nomor 18 Tahun 1999 tentang Jasa Konstruksi (Lembaran Negara Republik Indonesia Tahun 1999 Nomor 54, Tambahan Lembaran Negara Republik Indonesia Nomor 3833).
} 
Rencana Pembangunan Jangka Menengah Nasional (RPJMN) Tahun 2010-2014, yaitu melalui percepatan pembangunan infrastruktur yang memadai untuk peningkatan daya saing perekonomian dan pertumbuhan ekonomi nasional yang berkualitas. ${ }^{6}$

Dalam mendukung tujuan pembangunan tersebut, pengembangan jasa konstruksi diarahkan untuk memiliki daya saing dan kemampuan menyelenggarakan pekerjaan konstruksi secara lebih efisien dan efektif, sedangkan struktur usaha yang kokoh tercermin dengan terwujudnya kemitraan yang sinergis antar penyedia jasa, baik yang berskala besar, menengah, dan kecil, maupun yang berkualifikasi umum, spesialis, dan terampil, serta perlu diwujudkan pula ketertiban penyelenggaraan jasa konstruksi untuk menjamin kesetaraan kedudukan antara pengguna jasa dengan penyedia jasa dalam hak dan kewajiban.

Upaya pemerintah dalam mengembangkan jasa usaha konstruksi yang berkualitas, tepat waktu dan efisien secara normatif diformulasikan melalui Undang-Undang Nomor 18 Tahun 1999 tentang Jasa Konstruksi (UUJK) dan berbagai peraturan perundang-undangan pelaksana dari UUJK tersebut. Pengaturan jasa konstruksi dalam UUJK yang berlandaskan pada asas kejujuran dan keadilan, manfaat, keserasian, keseimbangan, kemandirian, keterbukaan, kemitraan, keamanan dan keselamatan demi kepentingan masyarakat, bangsa, dan negara, bertujuan untuk memberikan arah pertumbuhan dan perkembangan jasa konstruksi untuk mewujudkan struktur usaha yang kokoh, andal, berdaya saing tinggi, dan hasil pekerjaan konstruksi yang berkualitas; mewujudkan tertib penyelenggaraan pekerjaan konstruksi yang menjamin kesetaraan kedudukan antara pengguna jasa dan penyedia jasa dalam hak dan kewajiban, serta meningkatkan kepatuhan pada ketentuan peraturan perundang-undangan yang berlaku; dan mewujudkan peningkatan peran masyarakat di bidang jasa konstruksi. ${ }^{7}$

Namun kondisi dunia jasa konstruksi saat ini masih jauh dari yang dicita-citakan tersebut. Permasalahan yang melanda, yaitu mudahnya membuat perusahaan jasa konstruksi, hal ini menyebabkan jumlah perusahaan jasa konstruksi yang besar ${ }^{8}$ dengan latar belakang keberadaan dan kemampuannya yang sangat beragam dengan jumlah sekitar kurang lebih 90\% (sembilan puluh persen) adalah golongan kecil $^{9}$ yang masih membutuhkan waktu untuk dibina. Permasalahan lainnya adalah kemitraan yang sinergis antar penyedia jasa dalam berbagai klasifikasi dan/atau kualifikasi dalam iklim usaha yang bersih dan sehat, tertib hukum, beretika bisnis dan profesi belum terbangun, kemampuan manajemen; penguasaan teknologi

$6 \quad$ Lihat Lampiran Peraturan Presiden Nomor 5 Tahun 2010 tentang Rencana Pembangunan Jangka Menengah Nasional Tahun 2010 - 2014.

7 Lihat Pasal 2 dan 3 Undang-Undang Nomor 18 Tahun 1999 tentang Jasa Konstruksi (Lembaran Negara Republik Indonesia Tahun 1999 Nomor 54, Tambahan Lembaran Negara Republik Indonesia Nomor 3833).

8 Jumlah total badan usaha jasa konstruksi yang terregistrasi pada Lembaga Pengembangan Jasa Konstruksi Tahun 2012 adalah sebanyak 204.548 perusahaan. Sumber: http://www.lpjk.net/grafik-jasa-kontruksi.php, diakses tanggal 05 Juni 2012.

9. Ketua Lembaga Pengembangan Jasa Konstruksi Nasional (LPJKN), Tri Widjajanto mengatakan saat ini jumlah kontraktor saat ini 182.800 dengan proporsi $13 \%$ kontraktor nonkecil yang diduga menguasai $80 \%$ pasar, sedangkan $87 \%$ kontraktor kecil diduga hanya mampu merebut 20\% pasar (sumber: http://www.bisnis.com/ articles/jasa-konstruksi-kontraktor-kecil-butuh-perlindungan, diakses tanggal 14 Juli 2012). 
dan permodalan relatif lemah; lemahnya sumber daya manusia di bidang jasa konstruksi dengan keterbatasan tenaga ahli dan tenaga terampil yang tersebar merata di seluruh daerah; masih sangat menggantungkan diri pada proyek-proyek pemerintah; belum efektifnya asosiasi berperan dalam pembinaan pengembangan badan usaha anggotanya, kekurangsetaraan hubungan kerja antara pengguna jasa dan penyedia jasa, belum mantapnya dukungan di berbagai sektor secara langsung maupun tidak langsung yang mempengaruhi kinerja dan keandalan jasa konstruksi nasional, antara lain akses kepada permodalan, pengembangan profesi keahlian dan keterampilan, ketersediaan bahan bangunan yang standar; belum tertatanya pembinaan jasa kontruksi secara nasional, masih bersifat parsial dan sektoral, belum sepenuhnya tertata iklim usaha yang kondusif dalam: 1) kepranataan usaha, 2) pengembangan usaha 3) partisipasi masyarakat 4) pengaturan, pemberdayaan dan pengawasan. ${ }^{10}$

Terkait dengan kompleksnya permasalahan dunia konstruksi di Indonesia, maka pada perkembangannya saat ini DPR bersama Pemerintah sedang membahas Rancangan Undang-Undang (RUU) Perubahan Atas UndangUndang Nomor 18 Tahun 1999 tentang Jasa Konstruksi. RUU ini merupakan RUU Prioritas dalam Program Legislasi Nasional (Prolegnas) Tahun 2012. ${ }^{11}$ RUU ini sendiri merupakan RUU luncuran dari Prolegnas RUU Prioritas tahun
2011. ${ }^{12}$ Oleh karena itu, terkait dengan lama dan alotnya pembahasan RUU tersebut, penulis merasa penting untuk membahasnya dengan mencoba melakukan problem identification (menangkap realita/Das Sein yang terjadi) dan problem solving terutama dalam lingkup salah satu tujuan dibuat UUJK yaitu pengaturan pelaku jasa konstruksi dalam mewujudkan struktur usaha yang kokoh, andal, berdaya saing tinggi dan hasil pekerjaan konstruksi yang berkualitas.

\section{B. Permasalahan}

1. Bagaimana kondisi pengaturan jasa konstruksi saat ini dalam mewujudkan struktur usaha yang kokoh, andal, berdaya saing tinggi dan hasil pekerjaan konstruksi yang berkualitas?

2. Bagaimana arah pembaharuan regulasi konstruksi di masa depan dalam mewujudkan struktur usaha yang kokoh, andal, berdaya saing tinggi dan hasil pekerjaan konstruksi yang berkulitas?

\section{Metode Penelitian}

Penelitian ini bersifat normatif empirik, yaitu penelitian hukum yang mengkaji hukum tertulis dari berbagai aspek teori, sejarah, filosofi, perbandingan, struktur dan komposisi, lingkup dan materi, konsistensi, penjelasan umum dan pasal demi pasal, formalitas dan

10 Agus G. Kartasasmita, Pengadaan Barang / Jasa Pemerintah Menurut Pelaku Usaha (makalah) disampaikan pada Seminar Nasional dengan tema "Upaya Perbaikan Sistim Penyelenggaraan Barang / Jasa Pemerintah", diselenggarakan oleh Komisi Pengawas Persaingan Usaha (KPPU) dan Komisi Pemberantasan Korupsi (KPK), di Hotel Nikko Jakarta, 23 Agustus 2006.

11 Lihat Keputusan Dewan Perwakilan Rakyat Indonesia Nomor 08/DPR RI/II/2011-2012 tentang Program Legislasi Nasional Rancangan Undang-Undang Prioritas Tahun 2012.

12 Lihat Keputusan Dewan Perwakilan Rakyat Indonesia Nomor 02B/DPR RI/II/2010-2011 tentang Program Legislasi Nasional Rancangan Undang-Undang Prioritas Tahun Anggaran 2011. 
kekuatan mengikat suatu undang-undang, serta bahasa hukum yang digunakan. ${ }^{13}$ Penelitian normatif ini disebut juga sebagai penelitian hukum kepustakaan ${ }^{14}$ atau dapat juga disebut penelitian hukum doktrinal, yang bertujuan untuk menemukan jawaban yang benar dengan mendasarkan pada preskripsi-preskripsi hukum yang tertulis dan juga ajaran atau doktrin, ${ }^{15}$ dan lebih cenderung bersifat kualitatif (tidak berbentuk angka) berdasarkan data sekunder. ${ }^{16}$

Pendekatan analisa dalam penelitian ini adalah deskriptif kualitatif, yaitu tata cara penelitian yang menghasilkan data deskriptif terhadap permasalahan serta usaha pemecahannya. ${ }^{17}$ Analisa kualitatif dalam penelitian ini juga merupakan suatu usaha untuk menguraikan data secara bermutu dalam bentuk kalimat yang teratur, runtun, logis, tidak tumpang tindih dan efektif sehingga memudahkan interpretasi data dan pemahaman hasil analisis. ${ }^{18}$

Data yang digunakan dalam penelitian ini berupa data sekunder, yaitu berbagai informasi yang tertulis. Data sekunder yang digunakan berupa bahan hukum primer (primary sources or authorities), yaitu peraturan perundangundangan, dan bahan hukum sekunder (secondary sources or authorities), yaitu berupa buku-buku literatur, makalah-makalah dan berita dari internet. ${ }^{19}$

\section{Pembahasan}

1. Kondisi pengaturan jasa konstruksi saat ini terhadap struktur usaha yang kokoh, andal, berdaya saing tinggi dan hasil pekerjaan konstruksi yang berkulitas

Pertumbuhan sektor usaha jasa konstruksi yang ditandai dengan semakin meningkatnya jumlah badan usaha jasa konstruksi (BUJK) dan pasar konstruksi yang meningkat dari tahun ke tahun. Namun peningkatan tersebut belum berbanding lurus dalam mewujudkan struktur usaha jasa konstruksi yang kokoh, andal, berdaya saing tinggi dan menghasilkan produk konstruksi yang berkualitas.

Hal ini disebabkan oleh karena persyaratan usaha serta persyaratan keahlian dan keterampilan belum diarahkan untuk mewujudkan keandalan usaha yang profesional. Dengan tingkat kualifikasi dan kinerja tersebut, pada umumnya pangsa pasar pekerjaan konstruksi yang berteknologi tinggi belum sepenuhnya dapat dikuasai oleh usaha jasa konstruksi nasional. Kesadaran hukum dalam penyelenggaraan pekerjaan konstruksi perlu ditingkatkan, termasuk kepatuhan para pihak, yakni pengguna jasa dan penyedia jasa, dalam pemenuhan kewajibannya serta pemenuhan terhadap ketentuan yang terkait dengan aspek keamanan, keselamatan, kesehatan, dan

\footnotetext{
13 Abdulkadir Muhammad, Hukum dan Penelitian Hukum, (Bandung: Citra Aditya Bakti, 2004), hlm. 132

14 Rachmat Trijono (Ed.), Pola Penelitian dan Pengkajian Hukum Dalam Pembentukan Sistem Hukum Nasional, (Jakarta: Badan Pembinaan Hukum Nasional Kementerian Hukum dan Hak Asasi Manusia RI, 2011), hlm. 8

15 Soetandyo Wignjosoebroto, Ragam-ragam Penelitian Hukum. Dalam Irianto, Sulistyowati dan Shidarta (Ed.). Metode Penelitian Hukum Konstelasi dan Refleksi, (Jakarta: Yayasan Pustaka Obor Jakarta, 2011), hlm. 121.

16 J.Supranto, Metode Penelitian Hukum dan Statistik, (Jakarta: Rineka Cipta, 2003), hlm. 2.

17 Soerjono Soekanto, Pengantar Penelitian Hukum, (Jakarta: UI Press, 1986), hlm. 51.

18 Abdulkadir Muhammad, Hukum dan Penelitian Hukum, (Bandung: Citra Aditya Bakti, 2004).

19 C.F.G. Sunaryati Hartono, Penelitian Hukum Di Indonesia Pada Akhir Abad Ke-20, (Bandung: Alumni, 2006), hlm. 134.
} 
lingkungan, agar dapat mewujudkan bangunan yang berkualitas dan mampu berfungsi sebagaimana yang direncanakan.

Kondisi jasa konstruksi nasional dewasa ini sebagaimana tercermin dalam uraian tersebut di atas disebabkan oleh dua faktor: ${ }^{20}$

\section{a. faktor internal, yakni:}

1) pada umumnya jasa konstruksi nasional masih mempunyai kelemahan dalam manajemen, penguasaan teknologi, dan permodalan, serta keterbatasan tenaga ahli dan tenaga terampil;

2) struktur usaha jasa konstruksi nasional belum tertata secara utuh dan kokoh yang tercermin dalam kenyataan belum terwujudnya kemitraan yang sinergis antar penyedia jasa dalam berbagai klasifikasi dan/atau kualifikasi;

\section{b. faktor eksternal, yakni:}

1) kekurangsetaraan hubungan kerja antara pengguna jasa dan penyedia jasa;

2) belum mantapnya dukungan berbagai sektor secara langsung maupun tidak langsung yang mempengaruhi kinerja dan keandalan jasa konstruksi nasional, antara lain akses kepada permodalan, pengembangan profesi keahlian dan profesi keterampilan, ketersediaan bahan dan komponen bangunan yang standar;

3) belum tertatanya pembinaan jasa konstruksi secara nasional, masih bersifat parsial dan sektoral.
Berdasarkan penjelasan tersebut di atas, ruang lingkup pembahasan dalm tulisan ini akan mengungkapkan kondisi struktur usaha jasa konstruksi. Kondisi masuknya BUJK asing juga akan diungkapkan karena berkorelasi antara kesiapan struktur usaha jasa konstruksi nasional terhadap daya saing dengan BUJK asing. Kondisi pembinaan jasa konstruksi juga akan dibahas, karena keseriusan dan kejelasan dan kepastian program pembinaan jasa konstruksi akan membawa pada kesiapan struktur usaha industri konstruksi dalam menghadapi daya saing dengan sesama BUJK nasional maupun asing.

\section{a) Kondisi struktur usaha jasa konstruksi}

Jasa konstruksi nasional diharapkan semakin mampu mengembangkan perannya dalam pembangunan nasional melalui peningkatan keandalan yang didukung oleh struktur usaha yang kokoh dan mampu mewujudkan hasil pekerjaan konstruksi yang berkualitas. Struktur usaha yang kokoh tercermin dengan terwujudnya kemitraan yang sinergis antar penyedia jasa, baik yang berskala besar, menengah, dan kecil, maupun yang berkualifikasi umum, spesialis, dan terampil.

Relatif mudahnya mendirikan BUJK menyebabkan meningkatnya jumlah BUJK yang sangat signifikan saat ini. Regulasi merupakan salah satu faktor yang menyebabkan hal ini terjadi meskipun tidak dipungkiri adanya faktor-faktor lain. ${ }^{21}$ Industri konstruksi nasional melibatkan 182.800 BUJK dengan kualifikasi besar (1\%),

Lihat Penjelasan Umum UUJK.

21 Faktor-faktor lain tersebut terkait dengan sejarah perkembangan dunia jasa usaha konstruksi Indonesia, dimana pada awal dekade tujuh puluhan, dunia konstruksi Indonesia mulai mendapatkan angin, ketika Soeharto mencanangkan pembangunan yang bertumpu kepada terciptanya prasarana (infrastruktur) pembangunan ekonomi. Hingga pada dekade delapan puluh sampai dengan sembilan puluhan, pembangunan konstruksi mencapai klimaksnya atau "booming". 
kualifikasi menengah (12\%) dan kualifikasi kecil (87\%). Komposisi ini didominasi BUJK umum (general contractors) dan sedikit BUJK khusus (specialist contractors). Secara hipotetik, 85\% nilai pasar konstruksi dikuasai oleh non-kecil dengan jumlah $13 \%$ dari total 182.800 BUJK, sedangkan $15 \%$ nilai pasar konstruksi diperebutkan oleh BUJK kecil dengan jumlah $87 \%$ dari total 182.800 BUJK. ${ }^{22}$ Sebagai perbandingan, proporsi jumlah BUJK besar dan kecil ini dari tahun ke tahun menunjukan prosentase yang sama, hal ini dapat terlihat dari data tahun 2002 yang menunjukan bahwa jumlah BUJK besar jasa konstruksi hanya sekitar $1.1 \%$ saja dari total perusahaan jasa konstruksi Indonesia. Sementara 7\% tergolong ke dalam kelompok kontraktor menengah dan 91\% tergolong ke dalam kelompok kontraktor kecil. ${ }^{23}$

Fakta yang menunjukan bahwa struktur usaha yang kokoh, andal, dan berdaya saing belum terbentuk adalah dengan indikator jumlah kontraktor lebih dari 150.000 dan hampir 70\%$80 \%$ berada di Jawa. Kemitraan antara badan usaha besar, sedang, dan kecil belum terwujud secara sinergis, saling menguntungkan dan resiprokal. Disamping itu, jumlah kontraktor kecil lebih banyak bersifat umum dan tidak spesialis; jumlah kontraktor spesialis hampir tidak ada. Struktur industri konstruksi terfragmentasi sehingga banyak transaksi dan banyak kontrak. Dengan demikian, biaya transaksi tinggi sering terjadi. Seharusnya terdiferensiasi menjadi generalis dan spesialis bila diarahkan dapat terbangun dengan struktur yang seimbang.

Apabila dilihat dari komposisi BUJK besar, menengah dan kecil tersebut di atas terhadap nilai pasar konstruksi yang dikuasai BUJK besar, menengah dan kecil, maka kondisi struktur usaha jasa konstruksi saat ini Indonesia mengalami ketimpangan struktur pasar dan industri konstruksi. Keadaan ini menyebabkan persaingan usaha di pasar konstruksi skala kecil menjadi tidak sehat dan terdistorsi.

Struktur industri konstruksi nasional didominasi oleh BUJK berbagai skala bersifat umum. Spesialisasi BUJK masih belum berkembang dan spesialisasi dipandang akan mempersempit peluang usaha. Keterbatasan kesempatan usaha bagi BUJK skala kecil. BUJK skala besar seperti BUMN masih ditengarahi memiliki dominasi dan bahkan melakukan praktik mengambil pasar konstruksi skala kecil menengah serta ekploitasi subkontraktor.

Kontraktor besar dinilai belum ikut serta memberdayakan atau memberi kesempatan kepada kontraktor skala kecil lokal dimana pekerjaan konstruksi berada. Kapasitas, kompetensi dan

Banyaknya proyek konstruksi, sebagaimana hukum ekonomi tentang supply dan demand, yaitu terjadinya "Booming" lahirnya puluhan ribu, bahkan tercatat jumlah kontraktor di Indonesia hingga tahun 90-an pun telah mencapai 100 ribu. Karena jumlah perusahaan (pengusaha) kontraktor mengimbangi "demand" atau pasar konstruksi dalam negeri terutama proyek-proyek konstruksi yang dibiayai oleh APBN dan investor Luar Negeri. Market share tercapai. Maka hingga dekade sembilan puluh lima-an adalah merupakan masa-masa emas bagi pengusahakontraktordanjasakonstruksilainnya(BambangPranoto,NasionalismeKonstruksiIndonesia(makalah), disampaikan pada CivilEngineering Conference-Unika Soegijapranata di Semarang pada tanggal 17-18 Juni 2005).

22 Akhmad Suraji \& Krishna S Pribadi (Ed.), Membangun Struktur Industri Konstruksi Nasional Yang Kokoh, Andal Dan Berdayasaing Serta Memberikan Kesempatan Kepada Para Pelaku Usaha Tumbuh dan Berkembang Secara Adil Melalui Restrukturisasi Sistem, Diseminasi Hasil Rumusan Seminar Konstruksi Nasional Indonesia I Tahun 2012, diselenggarakan oleh Badan Pembinaan Konstruksi (BP-Konstruksi) Kementerian PU, Lembaga Pengembangan Jasa Konstruksi Nasional (LPJKN), dan GAPENSI).

23 Komisi Pengawas Persaingan Usaha, Position Paper KPPU Terhadap Perkembangan Sektor Jasa Konstruksi, (Jakarta: KPPU, tanpa tahun), hlm. 8 
daya saing kontraktor skala kecil terbatas. Permasalahan ini dipicu oleh keterbatasan kompetensi SDM, akses permodalan dan kemampuan peralatan/ teknologi. ${ }^{24}$

Kondisi usaha industri konstruksi yang didominasi pelaku usaha besar dikarenakan adanya kebutuhan pendanaan yang relatif besar dan juga pool of resources yang memungkinkan tercapainya skala ekonomis. Kontraktor lokal dan asing memiliki segmen pasarnya masingmasing terutama berkaitan dengan infrastruktur di sektor migas. Hambatan untuk masuk ke pasar cukup besar bagi pelaku usaha baru sehingga pertambahan pelaku usaha di sektor jasa konstruksi cenderung sangat minim. ${ }^{25}$

Hasil kajian KPPU memperlihatkan bahwa dalam industri jasa konstruksi, pelaku usaha berpotensi untuk melakukan pelanggaran terhadap Undang-Undang Nomor 5 Tahun 1999 tentang Larangan Praktek Monopoli dan Persaingan Usaha Tidak Sehat dalam beberapa bentuk kolusi tender; kartel; pemboikotan; menciptakan entry barrier melalui proses sertifikasi; menjadikan keanggotaan asosiasi sebagai entry barrier. ${ }^{26}$

Kondisi struktur usaha industri konstruksi yang tergambarkan di atas menyebabkan usaha industri konstruksi terbawa pada penilaian bahwa usaha industri kontruksi adalah (i) mengesankan menjaditempatpermainankotor,(ii)dimanfaatkan untuk meminta jatah, (iii) persaingan sangat keras dapat cenderung berbahaya, (iv) lebih berdasar keterampilan dari pada pengetahuan, (iv) banyak pekerjaan dilakukan dilapangan, (vi) biaya murah dan nilai tambah rendah; (vii) cara berhubungan yang cenderung memicu konflik/bersifat adversarial; (viii) terfragmentasi, terpecah pecah dan berasal dari banyak latar belakang berbeda dan (ix) entry barrier rendah dan persaingan berdasarkan harga murah. Secara umum kondisi tersebut menjadikan industri konstruksi kurang efisien, kurang produktif, kurang innovatif. ${ }^{27}$

\section{b) Kondisi Terhadap Kehadiran BUJK Asing}

Dalam kondisi ekonomilndonesia yang sedang membangun seperti sekarang ini, ternyata tidak semua kue pembangunan nasional dinikmati oleh BUJK nasional. Pasar konstruksi Indonesia yang besarnya sekitar Rp 208 triliun pada tahun 2011, ternyata yang menikmati adalah BUJK asing. Porsi yang dinikmati oleh BUJK asing itu, yaitu $70 \%$. Hal ini berarti dana konstruksi Indonesia yang terbang ke luar negeri, sekitar Rp 145,6 triliun. $^{28}$

Jumlah kontraktor dan konsultan asing yang masuk ke Indonesia mengalami peningkatan yang cukup pesat (22\%) sejak dicanangkannya program Masterplan Percepatan Perluasan dan Pembangunan Ekonomi Indonesia (MP3EI). Saat ini jumlahnya telah mencapai 262 BUJK yang sebagian besar berasal dari Jepang (77 BUJK), Korea Selatan (69 BUJK), China (42 BUJK), dan Eropa (33 BUJK). Ketua Umum Gabungan Pelaksana Konstruksi Nasional Indonesia (Gapensi) Soeharsojo mengatakan membanjirnya kontraktor asing seharusnya dapat

$24 \quad$ Akhmad Suraji \& Krishna S Pribadi (Ed.), Op.Cit.

25 Komisi Pengawas Persaingan Usaha, Persaingan Usaha dan Jasa Konstruksi (Makalah). Sumber: www.kppu.go.id, diakses tanggal 20 Juni 2012.

26 Ibid.

27 Ibid.

28 Agoes S. Soerono, Pasar Konstruksi Indonesia 70\% Digerogoti Asing, Harian Ekonomi Neraca, 20 Juni 2012, sumber: http://www.neraca.co.id/2012/06/20/pasar-konstruksi-indonesia-70-digerogoti-asing/, diakses tanggal 1 Juli 2012. 
menjadi kesempatan bagi kontraktor lokal untuk mendapatkan ilmu dan pengalaman baru. ${ }^{29}$

Ketergantungan pada teknologi, material dan peralatankonstruksidariluarnegerimenyebabkan pasar konstruksi nasional masih banyak dikuasai penyedia BUJK asing, terutama di sektor migas. Di sektor migas justru banyak "Barrier", sehingga BUJK nasional sulit memenuhi persyaratan kualifikasi, akibatnya tidak berkesempatan mengikuti pelelangan.

Kondisi usaha industri konstruksi yang juga dikuasai oleh BUJK asing membawa pada kehancuran BUJK nasional. Seharusnya kehadiran BUJK asing membawa pembaharuan dalam usaha industri konstruksi kita dalam hal transfer of konwledge, karena dari faktor pengetahuan dan teknologi yang digunakan oleh BUJK asing mungkin lebih tinggi dan berkualitas dari pada BUJK asing. Selain hal tersebut apabila dibandingkan dengan jumlah pelaku usaha nasional secara keseluruhan mungkin sangat sedikit, tetapi skala kemampuan finansial mereka yang sangat tinggi menyebabkan mereka cukup berperan dalam melakukan penetrasi pasarnya.

\section{c) Kondisi Pembinaan Terhadap Usaha Jasa Konstruksi}

Pelaksanaan pembinaan jasa konstruksi tidak semata-mata merupakan domain dari Pemerintah. Di dalam Pasal 35 UUJK disebutkan bahwa Pemerintah bersama-sama dengan masyarakat jasa konstruksi melaksanakan pembinaan jasa konstruksi. Dalam pelaksanaan pembinaan yang dilakukan bersama dengan masyarakat jasa konstruksi, pembinaan dilakukan oleh Pemerintah melalui suatu kegiatan dalam bentuk forum dan lembaga. Forum merupakan fasilitas dan/atau sarana untuk mendorong terciptanya pemanfaatan dan pengawasan secara optimal terhadap penyelenggaraan jasa konstruksi nasional bagi masyarakat pada umumnya dan atau masyarakat jasa konstruksi pada khususnya. Lembaga merupakan wadah pembinaan pelaksanaan pengembangan jasa konstruksi.

Peran asosiasi dan lembaga (dalam hal ini Lembaga Pengembangan Jasa Konstruksi Nasional / LPJKN) memiliki posisi yang sangat penting dalam proses pembinaan usaha industri jasa konstruksi. Namun kondisinya saat ini terjadi kegundahan tentang perkembangan asosiasi yang kontra produktif terhadap semangat UUJK, sehingga perlu adanya penataan Asosiasi dan LPJK agar kembali ke khitahnya sebagai lembaga yang dapat mengembangkan industri jasa konstruksi nasional.

Regulasi yang mengatur mengenai sertifikasi kontraktor dan klasifikasi bidang usaha jasa konstruksi, hingga saat ini aturan bakunya belum tegas. Kontraktor disinyalir dapat seenaknya mengantongi sertifikat. Begitu juga untuk mendirikan badan usaha, dapat dengan mudah memperoleh izin asalkan ada asosiasi anggota lembaga pengembangan jasa konstruksi (LPJK) yang menyetujuinya. Akibatnya, bermunculan asosiasi konstruksi dadakan yang didirikan hanya untuk kepentingan membidik proyek tertentu. ${ }^{30}$

Data menunjukan saat ini terdapat 38 (tiga puluh delapan) asosiasi badan usaha jasa konstruksi dan 43 (empat puluh tiga) asosiasi profesi jasa konstruksi. Asosiasi badan usaha jasa konstruksi adalah satu atau lebih wadah

Sumber: http://www.bisnis.com/articles/jumlah-kontraktor-asing-meningkat-pesat, diakses pada tanggal 15 Juni 2012.

30 A. Dadan Muhanda, Jasa Konstruksi Masuki Babak Baru, sumber: http://www.lkpp.go.id/v2/berita-detail. php?id=1668785862, diakses pada tanggal 15 Juli 2012. 
organisasi dan atau himpunan para pengusaha yang bergerak di bidang jasa konstruksi untuk memperjuangkan kepentingan dan aspirasi para anggotanya. Sedangkan Asosiasi profesi jasa konstruksi, adalah satu atau lebih wadah organisasi atau himpunan perorangan, atas dasar kesamaan disiplin keilmuan dibidang konstruksi atau kesamaan profesi dibidang jasa konstruksi, dalam usaha mengembangkan keahlian dan memperjuangkan aspirasi anggota. ${ }^{31}$

Asosiasi baru yang muncul bukan saja asosiasiasosiasi yang lebih spesialis bidangnya, tetapi juga asosiasi-asosiasi sejenis yang sudah ada dan bersifat umum. Padahal sebelum diberlakukannya UUJK, kita hanya mengenal Gapensi dan AKI sebagai asosiasi perusahaan kontraktor dan Inkindo untuk asosiasi perusahaan konsultan. Setelah 10 tahun usia UUJK, disinyalir munculnya asosiasi baru bukan karena kebutuhan anggota, tetapi seringkali karena merupakan tandingan dari asosiasi yang sudah ada akibat adanya konflik di tingkat elit pengurus asosiasi. Adanya aturan UUJK yang membuka peluang bagi asosiasi untuk melakukan sertifikasi, diduga menjadi salah satu daya tarik berdirinya asosiasi asoisasi, karena asosiasi lebih menjadi semacam profit-center daripada services-center. Kondisi semacam itu menyebabkan asosiasi-asosiasi tidak optimal atau bahkan merasa tidak perlu melakukan peningkatan profesionalisme anggota. Karena tanpa menjalankan fungsi pembinaan, asosiasiasosiasi tetap dibutuhkan karena sertifikatnya dapat memenuhi persyaratan dalam proses pengadaan barang dan jasa pemerintah. Padahal spirit dari UUJK adalah untuk memberikan arah pertumbuhan dan perkembangan jasa konstruksi untuk mewujudkan struktur usaha yang kokoh, andal, berdaya saing tinggi, dan hasil pekerjaan konstruksi yang berkualitas, dimana asosiasi sebagai ujung tombak dalam pembinaan profesionalisme penyedia jasa konstruksi. ${ }^{32}$

Kehadiran Lembaga Pengembangan Jasa Konstruksi (LPJK), dengan dua kewenangan utamanya yakni melakukan sertifikasi profesi dan sertifikasi badan usaha jasa konstruksi. Dalam praktek di lapangan seringkali kewenangan ini dijadikan sandaran bagi munculnya perilaku yang bertentangan dengan Undang-Undang Nomor 5 Tahun 1999, antara lain dalam bentuk hadirnya entry barrier berupa kesulitan mendapatkan sertifikasi badan usaha dalam bidang tertentu. ${ }^{33}$

Kewenangan Asosiasi mengeluarkan sertifikat digunakan sebagai alat untuk mendiskriminasi pelaku usaha pesaing, dengan cara: a) Sertifikat hanya diberikan kepada pelaku usaha yang berada di kelompok tertentu; b) Persyaratan sertifikat menjadi Entry Barrier bagi pelaku usaha pesaing. Kecenderungan untuk membentuk asosiasi tertentu dengan ruang lingkup pekerjaan yang semakin spesifik. Kehadiran asosiasi untuk menciptakan peluang memenangkan tender dan dimanfaatkan untuk tujuan tertentu. Kasus yang terjadi Asosiasi Aspal Beton Indonesia (AABI) telah mempraktekkan diri menjadi kartel (di Medan). Perkara ini pernah ditangani oleh KPPU. ${ }^{34}$

31 Pusat Pembinaan Usaha Dan Kelembagaan Badan Pembinaan Konstruksi - Kementerian Pekerjaan Umum, Tahun 2011. Sumber: http://www.jasakonstruksi.net/index.php/frontyard/article/index/asosiasi_bu dan http:// www.jasakonstruksi.net/index.php/frontyard/article/index/asosiasi_jakon, diakses pada tanggal 13 Juli 2012.

32 Mengantisipasi Dampak Perubahan Regulasi Bidang Jasa Konstruksi (Majalah trenKonstruksi edisi Juni 2010 ).

33 Komisi Pengawas Persaingan Usaha, Position Paper KPPU Terhadap Perkembangan Sektor Jasa Konstruksi, Op.Cit., hlm. 2.

34 Komisi Pengawas Persaingan Usaha, Persaingan Usaha dan Jasa Konstruksi (makalah). Sumber: www.kppu.go.id, diakses tanggal 20 Juni 2012. 


\section{Arah pembaharuan regulasi konstruksi di masa depan dalam mewujudkan struktur usaha yang kokoh, andal, berdaya saing tinggi dan hasil pekerjaan konstruksi yang berkulitas}

Beranjak dari tujuan dibuatnya UUJK, yaitu untuk memberikan arah pertumbuhan dan perkembangan jasa konstruksi untuk mewujudkan struktur usaha yang kokoh, andal, berdaya saing tinggi, dan hasil pekerjaan konstruksi yang berkualitas; mewujudkan tertib penyelenggaraan pekerjaan konstruksi yang menjamin kesetaraan kedudukan antara pengguna jasa dan penyedia jasa dalam hak dan kewajiban, serta mewujudkan peningkatan peran masyarakat di bidang jasa konstruksi, maka penulis berusaha meneliti apakah tujuan yang hendak dicapai itu menjadi suatu realita dalam usaha industri konstruksi. Realita yang dijumpai adalah adanya suatu keadaan yang belum mencapai tujuan dari dibuatnya regulasi, yaitu sebuah realita yang telah penulis deskripsikan di atas. Terjadinya kesenjangan antara tujuan ideal dan realita yang terjadi (Das Sollen dan Das Sein) tersebut di atas, maka penulis berusaha mengkajinya berdasarkan perspektif aspek legal substance atau materi muatan yang diatur di dalam UUJK dan peraturan perundang-undangan lainnya sebagai peraturan pelaksanaannya. Oleh karena itu pembahasan asas-asas hukum yang mendasari pembentukan UUJK dan peraturan pelaksananya akan menjadi sangat penting, karena apakah asas-asas hukum yang terdapat dalam UUJK benar-benar telah menjelma dalam mendasari materi muatan yang diatur dalam UUJK.

Asas-asas pembentukan peraturan perundang-undangan adalah suatu pedoman atau suatu rambu-rambu dalam pembentukan peraturan perundang-undangan yang baik. ${ }^{35}$

Paul Scholten dalam 'Algemeen Deel' mengungkapkan bahwa asas hukum (rechtsbenginsel) adalah penting untuk dapat melihat jalur "benang merah" dari sistem hukum positif yang ditelusuri dan diteliti. Melalui konstruksi dengan cara membatasi beberapa aturan tertentu menjadi aturan yang lebih mempunyai ruang lingkup atau tujuan yang umum, maka dapat dicari apa yang menjadi ratio legis atau tujuan umum aturan-aturan tersebut. ${ }^{36}$

Di dalam pembentukan peraturan perundang-undangan Indonesia, sebagaimana halnya di negara lain, terdapat dua asas hukum yang perlu diperhatikan, yaitu asas hukum umum yang khusus memberikan pedoman dan bimbingan bagi "pembentukan" isi peraturan, dan asas hukum lainnya yang memberikan pedoman dan bimbingan bagi penuangan peraturan ke dalam bentuk dan susunannya, bagi metode pembentukannya, dan bagi proses serta prosedur pembentukannya. ${ }^{37}$

Di dalam Pasal 5 dan 6 Undang-Undang No. 12 Tahun 2011 tentang Pembentukan Peraturan Perundang-undangan disebutkan bahwa Dalam membentuk Peraturan Perundang-undangan harus dilakukan berdasarkan pada asas Pembentukan Peraturan Perundang-undangan yang baik, yang meliputi: a) kejelasan tujuan;

\footnotetext{
35 Maria Farida Indrati S., Ilmu Perundang-undangan: Jenis, Fungsi, dan Materi Muatan, (Jakarta: Kanisius, 2007), hlm. 252.

36 A. Hamid S. Attamimi, Peranan Keputusan Presiden Republik Indonesia Dalam Penyelenggaraan Pemerintahan Negara, Suatu Studi Analisis Mengenai Keputusan Presiden Yang Berfungsi Pengaturan Dalam Kurun Waktu Pelita I - Pelita IV (Disertasi), (Jakarta, Fakultas Pascasarjana UI, 1990), hlm. 299.

37 Ibid., hlm. 304.
} 
b) kelembagaan atau pejabat pembentuk yang tepat; c) kesesuaian antara jenis, hierarki, dan materi muatan; d) dapat dilaksanakan; e) kedayagunaan dan kehasilgunaan; f) kejelasan rumusan; dan g) keterbukaan. Kemudian Materi muatan Peraturan Perundang-undangan harus mencerminkan asas: a) pengayoman; b) kemanusiaan; c) kebangsaan; d) kekeluargaan; e) kenusantaraan; f) bhinneka tunggal ika; g) keadilan; h) kesamaan kedudukan dalam hukum dan pemerintahan; i) ketertiban dan kepastian hukum; dan/atau j) keseimbangan, keserasian, dan keselarasan. Selain mencerminkan asas sebagaimana tersebut di atas, Peraturan Perundang-undangan tertentu dapat berisi asas lain sesuai dengan bidang hukum Peraturan Perundang-undangan yang bersangkutan.

Di dalam UUJK, pengaturan jasa konstruksi berlandaskan pada asas kejujuran dan kea- dilan, $^{38}$ manfaat, $^{39}$ keserasian, $^{40}$ keseimbangan, ${ }^{41}$ kemandirian, ${ }^{42}$ keterbukaan, ${ }^{43}$ kemitraan, ${ }^{44}$ keamanan dan keselamatan demi kepentingan masyarakat, bangsa, dan negara. ${ }^{45}$

Berdasarkan asas-asas yang terdapat dalam UUJK tersebut penulis akan mengkaji apakah keberadaan asas-asas tersebut melandasi materi muatan yang terkait permasalahan struktur usaha jasa konstruksi, pengaturan BUJK asing dan pembinaan jasa usaha konstruksi, yang akan diuraikan di bawah ini.

\section{a) Pembaharuan regulasi struktur usaha jasa konstruksi}

Bahwa indikator struktur usaha jasa konstruksi yang kokoh tercermin dari terwujudnya kemitraan yang sinergis antar penyedia jasa, baik yang berskala besar, menengah, dan kecil, maupun yang berkualifikasi umum, spesialis, dan terampil.

38 Asas Kejujuran dan Keadilan mengandung pengertian kesadaran akan fungsinya dalam penyelenggaraan tertib jasa konstruksi serta bertanggung jawab memenuhi berbagai kewajiban guna memperoleh haknya (Lihat Penjelasan Pasal 2 UUJK).

39 Asas Manfaat mengandung pengertian bahwa segala kegiatan jasa konstruksi harus dilaksanakan berlandaskan pada prinsip-prinsip profesionalitas dalam kemampuan dan tanggung jawab, efisiensi dan efektifitas yang dapat menjamin terwujudnya nilai tambah yang optimal bagi para pihak dalam penyelenggaraan jasa konstruksi dan bagi kepentingan nasional (Lihat Penjelasan Pasal 2 UUJK).

40 Asas Keserasian mengandung pengertian harmoni dalam interaksi antara pengguna jasa dan penyedia jasa dalam penyelenggaraan pekerjaan konstruksi yang berwawasan lingkungan untuk menghasilkan produk yang berkualitas dan bermanfaat tinggi (Lihat Penjelasan Pasal 2 UUJK).

41 Asas Keseimbangan mengandung pengertian bahwa penyelenggaraan pekerjaan konstruksi harus berlandaskan pada prinsip yang menjamin terwujudnya keseimbangan antara kemampuan penyedia jasa dan beban kerjanya. Pengguna jasa dalam menetapkan penyedia jasa wajib mematuhi asas ini, untuk menjamin terpilihnya penyedia jasa yang paling sesuai, dan di sisi lain dapat memberikan peluang pemerataan yang proporsional dalam kesempatan kerja pada penyedia jasa

42 Asas Kemandirian mengandung pengertian tumbuh dan berkembangnya daya saing jasa konstruksi nasional (Lihat Penjelasan Pasal 2 UUJK).

43 Asas Keterbukaan mengandung pengertian ketersediaan informasi yang dapat diakses sehingga memberikan peluang bagi para pihak, terwujudnya transparansi dalam penyelenggaraan pekerjaan konstruksi yang memungkinkan para pihak dapat melaksanakan kewajiban secara optimal dan kepastian akan hak dan untuk memperolehnya serta memungkinkan adanya koreksi sehingga dapat dihindari adanya berbagai kekurangan dan penyimpangan (Lihat Penjelasan Pasal 2 UUJK).

44 Asas Kemitraan mengandung pengertian hubungan kerja para pihak yang harmonis, terbuka, bersifat imbal balik, dan sinergis (Lihat Penjelasan Pasal 2 UUJK).

45 Asas Keamanan dan Keselamatan mengandung pengertian terpenuhinya tertib penyelenggaraan jasa konstruksi, keamanan lingkungan dan keselamatan kerja, serta pemanfaatan hasil pekerjaan konstruksi dengan tetap memperhatikan kepentingan umum (Lihat Penjelasan Pasal 2 UUJK). 
Seperti yang telah dijelaskan di atas bahwa realita yang terjadi adalah BUJK kecil berjumlah yaitu berjumlah $87 \%$, namun ironisnya kue pasar konstruksi yang mereka nikmati hanya sebesar $15 \%$ dari total pasar konstruksi.

Struktur usaha industri konstruksi yang timpang tersebut, secara normatif didasarkan pada lemahnya regulasi, yaitu terkait pengaturan perizinan usaha jasa konstruksi yang relatif mudah; ruang lingkup jenis usaha jasa konstruksi; bentuk usaha jasa konstruksi; dan bidang usaha jasa konstruksi.

Terkait dengan perizinan jasa usaha konstruksi, BUJK yang menyelenggarakan usaha jasa konstruksi wajib memiliki izin usaha yang dikeluarkan oleh Pemerintah Daerah di tempat domisilinya. ${ }^{46}$ Namun untuk mengantisipasi ketidak seragaman/keteraturan pengaturan pemberian Izin Usaha Jasa Konstruksi (IUJK) di berbagai daerah dan untuk memberikan kepastian hukum serta untuk melindungi kepentingan masyarakat dan pembinaan dibidang jasa konstruksi, pemerintah memberlakukan Peraturan Menteri Pekerjaan Umum Nomor 04/PRT/M/2011 tentang Pedoman Persyaratan Pemberian Izin Usaha Jasa Konstruksi Nasional.

Pemberian IUJK akan diberikan kepada BUJK apabila memenuhi persyaratan sebagai berikut: ${ }^{47}$

a. mengisi Formulir Permohonan;

b. menyerahkan rekaman Akta Pendirian BUJK; c. menyerahkan rekaman Sertifikat Badan Usaha (SBU) yang telah diregistrasi oleh Lembaga;

d. menyerahkan rekaman Sertifikat Keahlian (SKA) dan/atau Sertifikat Keterampilan (SKT) dari Penanggung Jawab Teknik Badan Usaha (PJT-BU) yang telah diregistrasi oleh Lembaga;

e. menyerahkan rekaman Kartu Penanggung Jawab Teknik Badan Usaha (PJT-BU) yang dilengkapi surat pernyataan pengikatan diri Tenaga Ahli/Terampil dengan Penanggung Jawab Utama Badan Usaha (PJU-BU).

Pengaturan bagi usaha orang perorangan yang akan menyelenggarakan usaha jasa konstruksi cukup dengan kewajiban memiliki SKA/SKT dan terdaftar pada unit kerja / instansi pemberi IUJK dan diberikan Kartu Tanda Daftar. ${ }^{48}$

Apabila melihat persyaratan-persyaratan di atas dalam hal untuk mendapat IUJK, maka hal yang pokok atau syarat mutlak untuk dimiliki terlebih dahulu oleh BUJK adalah SBU dan SKA/ SKT. Persyaratan administrasi yang relatif mudah tersebut mengakibatkan kondisi usaha jasa konstruksi saat ini jauh dari proporsional yang diidamkan oleh pembentuk peraturan. Kemudian pertanyaannya adalah siapa yang berwenang menerbitkan SBU dan SKA/SKT tersebut. Hal ini akan dibahas pada masalah regulasi pembinaan jasa konstruksi.

Kemudian mengenai ruang lingkup jenis usaha jasa usaha konstruksi, berdasarkan Pasal 1

$46 \quad$ Lihat Pasal 14 ayat (1) Peraturan Pemerintah Nomor 28 Tahun 2000 tentang Usaha dan Peran Masyarakat Jasa Konstruksi. Pemerintah Kabupaten / Kota memiliki wewenang untuk memberikan IUJK kepada badan usaha jasa konstruksi berdasarkan tempat domisili (Lihat Pasal 4 Peraturan Menteri Pekerjaan Umum Nomor 04/PRT/ M/2011 tentang Pedoman Persyaratan Pemberian Izin Usaha Jasa Konstruksi Nasional).

47 Lihat Pasal 8 UUJK jo. Pasal 14 Peraturan Pemerintah Nomor 28 Tahun 2000 jo. Pasal 6 ayat (1) Peraturan Menteri Pekerjaan Umum Nomor 04/PRT/M/2011.

48 Lihat Pasal 9 ayat (1-2) UUJK jo. Pasal 9 ayat (1-2) Peraturan Pemerintah Nomor 4 Tahun 2010 jo. Pasal 9 ayat (1-2) Peraturan Menteri Pekerjaan Umum Nomor 04/PRT/M/2011. 
angka (2) UUJK disebutkan bahwa yang dimaksud dengan Jasa Konstruksi adalah layanan jasa konsultansi perencanaan pekerjaan konstruksi, layanan jasa pelaksanaan pekerjaan konstruksi, dan layanan jasa konsultansi pengawasan pekerjaan konstruksi. Kemudian di dalam Pasal 1 angka (3) UUJK disebutkan yang dimaksud dengan Pekerjaan Konstruksi adalah Pekerjaan konstruksi adalah keseluruhan atau sebagian rangkaian kegiatan perencanaan dan/atau pelaksanaan beserta pengawasan yang mencakup pekerjaan arsitektural, sipil, mekanikal, elektrikal, dan tata lingkungan masing-masing beserta kelengkapannya, untuk mewujudkan suatu bangunan atau bentuk fisik lain. Berdasarkan Pasal tersebut secara garis besar ruang lingkup jenis usaha jasa konstruksi kita terbagi menjadi 3 (tiga), yaitu:

i. Jasa Konsultasi Perencanaan untuk pekerjaan arsitektural, sipil, mekanikal, elektrikal, dan tata lingkungan;

ii. Jasa Pelaksanaan untuk pekerjaan arsitektural, sipil, mekanikal, elektrikal, dan tata lingkungan; dan

iii. Jasa Konsultansi Pengawasan untuk pekerjaan arsitektural, sipil, mekanikal, elektrikal, dan tata lingkungan.

Ruang lingkup pekerjaan arsitektural, sipil, mekanikal, elektrikal, dan tata lingkungan dijabarkan di dalam Pasal 7 ayat (1) Peraturan Pemerintah Nomor 28 Tahun 2000 tentang Usaha dan Peran Masyarakat Jasa Konstruksi, yaitu:

i. Bidang pekerjaan Arsitektural antara lain arsitektur bangunan berteknologi sederhana, arsitektur bangunan berteknologi menengah, arsitektur bangunan berteknologi tinggi, arsitektur ruang dalam bangunan (interior), arsitektur lansekap, termasuk perawatannya. ii. Bidang pekerjaan Sipil, antara lain jalan dan jembatan, jalan kereta api, landasan, terowongan, jalan bawah tanah, saluran drainase dan pengendalian banjir, pelabuhan, bendung/bendungan, bangunan dan jaringan pengairan atau prasarana sumber daya air, struktur bangunan gedung, geoteknik, konstruksi tambang dan pabrik, termasuk perawatannya, dan pekerjaan penghancuran bangunan (demolition).

iii. Bidang pekerjaan Mekanikal, antara lain instalasi tata udara/AC, instalasi minyak/gas/ geotermal, instalasi industri, isolasi termal dan suara, konstruksi lift dan eskalator, perpipaan, termasuk perawatannya.

iv. Bidang pekerjaan Elektrikal, antara lain instalasi pembangkit, jaringan transmisi dan distribusi, instalasi listrik, sinyal dan telekomunikasi kereta api, bangunan pemancar radio, telekomunikasi dan sarana bantu navigasi udara dan laut, jaringan telekomunikasi, sentral telekomunikasi, instrumentasi, penangkal petir, termasuk perawatannya.

v. Bidang pekerjaan Tata Lingkungan, antara lain penataan perkotaan/ planologi, analisa dampak lingkungan, teknik lingkungan, tata lingkungan lainnya, pengembangan wilayah, bangunan pengolahan air bersih dan pengolahan limbah, perpipaan air bersih dan perpipaan limbah, termasuk perawatannya. Namun ruang lingkup bidang pekerjaan sebagaimana diatur di atas dipersempit dengan diberlakukannya Peraturan Pemerintah Nomor 4 Tahun 2010 tentang Perubahan Atas Peraturan Pemerintah Nomor 28 Tahun 2000 tentang Usaha dan Peran Masyarakat Jasa Konstruksi. Di dalam Pasal 7 ayat (1 dan 2) Peraturan Pemerintah Nomor 4 Tahun 2010 disebutkan bahwa bidang usaha jasa perencanaan dan pengawasan konstruksi 
terdiri atas bidang usaha yang bersifat umum dan spesialis dan bidang usaha jasa pelaksana konstruksi terdiri atas bidang usaha yang bersifat umum, spesialis dan keterampilan.

Berdasarkan bidang usaha tersebut, diklasifikasikan $^{49}$ menjadi: a) arsitektur; b) rekayasa (engineering); c) penataan ruang dan d) jasa konsultasi lainnya untuk bidang usaha jasa perencaan dan pengawasan, sedangkan untuk bidang usaha jasa pelaksanaan konstruksi diklasifikasikan menjadi: a) bangunan gedung; b) bangunan sipil; c) instalasi mekanikal dan elektrikal; dan jasa pelaksanaan lainnya. Dari klasifikasi bidang usaha tersebut dikualifikasikan menjadi: a) kualifikasi usaha besar; b) kualifikasi usaha menengah; dan kualifikasi usaha kecil.

Pembahasan selanjutnya adalah bagaimana hubungan antara jenis usaha, bentuk usaha dan bidang usaha beserta klasifikasi dan kualifikasi bidang usaha tersebut di atas dalam menciptakan suatu struktur usaha industri konstruksi yang kokoh dan handal? Berdasarkan hasil kajian secara normatif terhadap UUJK maupun peraturan perundang-undangan pelaksanaanya tidak ditemukan pengaturan hubungan hukum antara sesama BUJK maupun suatu kewajiban dari pengguna jasa konstruksi untuk memperhatikan kelangsungan usaha BUJK.

Pengaturan mengenai struktur usaha industri konstruksi di dalam UUJK hanya mengatur bahwa usaha jasa konstruksi dikembangkan untuk mewujudkanstrukturusahayangkokoh danefisien melalui kemitraan yang sinergis antara usaha yang besar, menengah, dan kecil serta antara usaha yang bersifat umum, spesialis, dan keterampilan tertentu. ${ }^{50} \mathrm{Di}$ dalam penjelasan pengaturan tersebut disebutkan bahwa dengan pendekatan ini diharapkan terwujud restrukturisasi bidang usaha jasa konstruksi yang menunjang efisiensi usaha, karena kemampuan penyedia jasa baik dalam skala usaha maupun kualifikasi usaha akan saling mengisi dalam kemitraan yang sinergis dan komplementer, karena saling memerlukan, yang dalam hubungan transaksionalnya dilandasi oleh kesetaraan dalam hak dan kewajiban.

Selain hal tersebut pengaturan mengenai hubungan kerja antara BUJK, diatur dalam Pasal 24 ayat (1) UUJK. Di dalam pasal tersebut disebutkan bahwa Penyedia Jasa dalam penyelenggaraan pekerjaan konstruksi dapat menggunakan subpenyedia jasa yang mempunyai keahlian khusus sesuai dengan masing-masing tahapan pekerjaan konstruksi. Di dalam penjelasan pasal tersebut dijelaskan bahwa pengikutsertaan subpenyedia jasa dibatasi oleh adanya tuntutan pekerjaan yang memerlukan keahlian khusus dan ditempuh melaluimekanisme subkontrak, dengan tidak mengurangi tanggung jawab penyedia jasa terhadap seluruh hasil pekerjaannya. Bagian pekerjaan yang akan dilaksanakan subpenyedia jasa harus mendapat persetujuan pengguna jasa. Pengikutsertaan subpenyedia jasa bertujuan memberikan peluang bagi subpenyedia jasa yang mempunyai keahlian spesifik melalui mekanisme keterkaitan dengan penyedia jasa.

Ketentuan Pasal 24 ayat (1) di atas, bukanlah suatu keharusan yang dibebankan UUJK terhadap penyedia jasa dalam meng-subkan

$49 \quad$ Klasifikasi adalah bagian kegiatan registrasi untuk menetapkan penggolongan usaha di bidang jasa konstruksi menurut bidang dan sub bidang usaha atau penggolongan profesi keterampilan dan keahlian kerja orang perseorangan di bidang jasa konstruksi menurut disiplin keilmuan dan/atau keterampilan tertentu dan/atau kefungsian dan/atau keahlian masing-masing (Lihat Pasal 1 ayat (2) Peraturan Pemerintah Nomor 4 Tahun 2010).

50 Lihat Pasal 12 UUJK. 
pekerjaannya kepada penyedia jasa. Frasa 'dapat' dalam pasal tersebut mengandung arti suatu pilihan hukum, dalam arti penyedia jasa boleh menggunakan subpenyedia jasa dan juga boleh tidak menggunakan subpenyedia jasa.

Asas Kemitraan yang mengandung pengertian hubungan kerja para pihak yang harmonis, terbuka, bersifat timbal balik, dan sinergis yang melandasi pengaturan di dalam UUJK pada dasarnya telah menjelma dari pengaturan di atas. Namun belum memuat suatu norma yang mengatur bagaimana bentuk/pola dan hubungan dari kemitraan sinergis antara usaha yang besar, menengah, dan kecil serta antara usaha yang bersifat umum, spesialis, dan keterampilan tertentu. Pengaturan ini penting karena di dalamnya memuat bagaimana hak dan kewajiban antara usaha BUJK tersebut serta apa yang diperbolehkan atau tidak boleh diantara mereka. Selain pengaturan tersebut, penting juga mengatur peran pemerintah dalam membuat suatu regulasi pengadaan barang dan jasa dalam mengakomodir keberadaan BUJK dalam membentuk hubungan transaksionalnya dilandasi oleh kesetaraan dalam hak dan kewajiban.

Sebagai bahan perbandingan struktur usaha industri konstruksi, maka tidak salah apabila kita melihat upaya negara lain dalam menciptakan struktur usaha industri konstruksi yang kokoh.

Negara-negara seperti USA, Jepang dan UK serta China memiliki postur kontraktor umum dan spesialis yang proporsional. Komposisi kontraktor generalis dan kontraktor spesialis seperti Jepang, Amerika dan Inggris memiliki komposisi hampir 30:70 dan China dengan 50:50. Sebelum tahun 2001, China mengalami jumlah kontraktor sebanyak 90.000 perusahaan dengan komposisi $74 \%$ umum; $26 \%$ spesialis. Sesudah 2002, Pemerintah China melakukan restrukturisasi sehingga menjadi 64.600 perusahaan dengan $52 \%$ umum dan $48 \%$ spesialis melalui suatu new qualification standards dan pembinaan yang progresif. Workshop terbatas Gapensi dan Tsinghua University (Beijing, 20 Juli 2012) dan diskusi Gapensi dan CHINCA (Beijing, 20 Juli 2012) menginformasikan bahwa jumlah kontraktor di China kurang lebih 30.000. Struktur klasifikasi dan kualifikasi kontraktor di China, sangat natural; struktur kontraktor berbentuk piramid dengan kontraktor besar: jumlah sedikit; harus mampu memperbesar skala ekonomi, cross region; transnational, multi project. Kemudian kontraktor spesialis biasanya perusahaan kecil, kemampuan terbatas, perlu fleksibel, responsif kepada pasar dan jumlah seharusnya bisa banyak jika dibina dengan baik. Dalam hal ini, faktor yang mempengaruhi demand kontraktor spesialis akan sangat tergantung ada tidaknya kontraktor besar serta peluang usaha terbatas, ada proteksi regional dan departemental, kompetisi dari kontraktor asing rendah dan ada proteksi. ${ }^{51}$

\section{b) Pembaharuan regulasi kehadiran BUJK Asing}

Pemberian izin bagi BUJK asing yang akan menyelenggarakan usaha jasa konstruksi di Indonesia diatur di dalam Pasal 14 ayat (4) Peraturan Pemerintah Nomor 28 Tahun 2000 dan secara teknis diatur di dalam Peraturan Menteri Pekerjaan Umum Nomor 05/PRT/M/2011 tentang Pedoman Persyaratan Pemberian Izin Perwakilan Badan Usaha Jasa Konstruksi Asing. BUJK asing yang akan menyelenggarakan usaha jasa usaha konstruksi di Indonesia wajib memiliki

51 Akhmad Suraji \& Krishna S Pribadi (Ed.), Op.Cit. 
Izin Perwakilan BUJK Asing. ${ }^{52}$ Izin Perwakilan BUJK Asing diberikan oleh Menteri atau Pejabat yang ditunjuk atas nama Menteri dan hanya diberikan kepada BUJK yang memiliki kualifikasi besar. ${ }^{53}$

Keberadaan BUJK asing di dalam UUJK diakui, yaitu dalam hal pelaksanaan pekerjaan konstruksi yang berisiko besar dan/atau yang berteknologi tinggi dan/atau yang berbiaya besar. Pengaturan mengenai kriteria pekerjaan apa saja yang dapat dilakukan, dan pengaturan pola hubungan dengan BUJK nasional dan hak dan kewajiban BUJK asing tidak diatur dalam UUJK. Formula pengaturan BUJK asing di dalam UUJK dipersamakan dengan BUJK nasional dengan kualifikasi besar. Dengan kondisi BUJK yang belum cukup mampu bersaing dengan BUJK asing yang secara kemampuan teknologi dan finansial lebih tinggi dari BUJK nasional, maka pembiaran kondisi seperti ini tidak mendasarkan pada asas keadilan, asas kemadirian dan asas keseimbangan.

Pengaturan BUJK asing secara lebih mendalam justru diatur dalam Peraturan Menteri Pekerjaan Umum Nomor 05/PRT/M/2011 tentang Pedoman Persyaratan Pemberian Izin Perwakilan Badan Usaha Jasa Konstruksi Asing. Materi muatan yang diatur dalam Permen tersebut lebih mempunyai nilai fungsi sebagai materi muatan yang seharusnya dimuat dalam undangundang dalam hal UUJK. Sesuai dengan Pasal 10 ayat (1) Undang-Undang No. 12 Tahun 2011, bahwa materi muatan yang harus diatur dalam undang-undang salah satunya berisi ketentuan mengenai pemenuhan kebutuhan hukum dalam masyarakat.

Oleh karena itu pengaturan BUJK asing dalam UUJK lebih diperluas dan dipertegas kembali sehingga tercipta struktur usaha yang lebih kokoh dan besinergis antara BUJK nasional dengan BUJK asing.

\section{c) Pembaharuan regulasi pembinaan jasa usaha konstruksi}

Pemerintah berdasarkan Pasal 35 ayat (1-5) UUJK melakukan pembinaan jasa konstruksi dalam bentuk pengaturan, pemberdayaan, dan pengawasan, dan pelaksanaan pembinaan tersebut dapat dilakukan bersama-sama dengan masyarakat jasa konstruksi.

Masyarakat jasa konstruksi di Indonesia dalam realitas keberadaannya dipengaruhi berbagai hal. Pertama, Lingkungan eksternal, dalam hal ini menyangkut kecenderungan global jasa konstruksi, situasi moneter, keamanan nasional, dinamika politik hingga regulasi yang dibuat. Kedua, lingkungan internal, dalam hal ini kondisi yang dialami masyarakat jasa konstruksi, baik secara sendiri-sendiri maupun jaringan keasosiasian. Pemahaman terhadap lingkungan kebijakan adalah cara untukmemahami konstelasi posisional jasa konstruksi. ${ }^{54}$

Masyarakat jasa konstruksi merupakan bagian dari masyarakat yang mempunyai kepentingan dan/atau kegiatan yang berhubungan dengan usaha dan pekerjaan jasa

52 Pengertian BUJK Asing adalah badan usaha yang didirikan menurut hukum dan berdomisili di negara asing, memiliki kantor perwakilan di Indonesia, dan dipersamakan dengan badan hukum Perseroan Terbatas yang bergerak di bidang usaha jasa konstruksi (lihat Pasal 1 angka (3) Peraturan Menteri Pekerjaan Umum Nomor 05/PRT/M/2011).

53 Penetapan memiliki kualifikasi besar didapatkan setelah BUJK Asing mendapatkan penyetaraan klasifikasi dan kualifikasi yang dinyatakan dalam bentuk sertifikat dari Lembaga (lihat Pasal 4 ayat (3) Peraturan Menteri Pekerjaan Umum Nomor 05/PRT/M/2011).

54 Iwan Kartiwan, Kamajaya Al Katuuk, Hendra N. Soenardji, WajahJasa Konstruksi Indonesia, Tinjauan Keberpihakan, (Jakarta: Gramedia Pustaka Utama, 2010), hlm. 9. 
konstruksi. ${ }^{55}$ Apabila melihat unsur-unsur ${ }^{56}$ yang terdapat dalam masyarakat jasa konstruksi, maka dapat diibaratkan masyarakat jasa konstruksi merupakan induk dari segala kegiatan konstruksi di Indonesia yang berperan dalam pengembangan jasa konstruksi dan juga melakukan pembinaan jasa konstruksi.

Keterlibatan peran masyarakat jasa konstruksi yang cukup besar dalam pembinaan (pengaturan, pemberdayaan dan pengawasan) yang dalam pelaksanaan pengembangannya dilaksanakan oleh suatu forum jasa konstruksi dan lembaga menimbulkan suatu permasalahan tersendiri.

Tugas dan wewenang dari lembaga yang begitu besar menimbulkan permasalahan yaitu peran pembinaan pemerintah belum efektif dan kurang tegas dinyatakan siapa yang mewakili pemerintah. Disamping itu, koordinasi yang lemah antara stakeholders dan saling mengharapkan antara pemerintah dan LPJKN/D. Peran LPJKN/D terbatas dan kemampuan pendanaan yang terbatas. Disamping itu, lembaga ini tidak sepenuhnya mendapat dukungan pendanaan dari pemerintah. Dalam kondisi keterbatasan tersebut, konsentrasi peran masih sebatas sertifikasi dan registrasi badan usaha, tenaga ahli dan tenaga terampil. Sistem dan tatakelola proses sertifikasi masih diwarnai oleh conflict of interest dan juga menciptakan adanya barrier dalam proses sertifikasi.
Oleh karena itu untuk mendapatkan suatu kepastian hukum dan mencegah adanya conflict of interest, proses pembinaan dalam kerangka penerbitan SBU perlu dilakukan perubahan tata kelola sertifikasi badan usaha dan profesi. Perlunya pengaturan dan penataan terhadap asosiasi dan penyelenggaraan proses sertifikasi yang akuntabel. Penataan asosiasi diperlukan, karena asosiasi memiliki fungsi mendasar, yaitu untuk melakukan pembinaan anggotanya, baik aspek profesionalisme, pengembangan pasar, dan perlindungan maupun penegakkan etika profesi. Dengan demikian fungsi asosiasi bukan hanya memproduksi KTA dan SBU/SKA semata.

\section{E. Penutup}

Struktur usaha yang kokoh tercermin dengan terwujudnya kemitraan yang sinergis antar penyedia jasa, baik yang berskala besar, menengah, dan kecil, maupun yang berkualifikasi umum, spesialis, dan terampil. Kondisi kemitraan antara badan usaha besar, sedang, dan kecil belum terwujud secara sinergis, saling menguntungkan dan resiprokal, disamping itu, jumlah kontraktor kecil lebih banyak bersifat umum. Kondisi tersebut menyebabkan struktur usaha jasa konstruksi saat ini Indonesia mengalami ketimpangan struktur pasar dan industri konstruksi. Keadaan ini menyebabkan persaingan usaha di pasar konstruksi skala kecil menjadi tidak sehat dan 
terdistorsi. Selain hal itu kondisi usaha industri konstruksi yang juga dikuasai oleh BUJK asing membawa pada kehancuran BUJK nasional. Seharusnya kehadiran BUJK asing membawa pembaharuan dalam usaha industri konstruksi kita dalam hal transfer of konwledge. Peran pembinaan yang tidak berjalan juga menambah permasalahan. Peran asosiasi dan lembaga (dalam hal ini Lembaga Pengembangan Jasa Konstruksi Nasional / LPJKN) memiliki posisi yang sangat penting dalam proses pembinaan usaha industri jasa konstruksi. Namun kondisinya saat ini terjadi kegundahan tentang perkembangan asosiasi yang kontra produktif terhadap semangat UUJK. Kontraktor disinyalir dapat seenaknya mengantongi sertifikat. Begitu juga untuk mendirikan badan usaha.

Berdasarkan hasil kajian secara normatif terhadap UUJK maupun peraturan perundangundangan pelaksanaanya tidak ditemukan pengaturan hubungan hukum antara sesama BUJK maupun suatu kewajiban dari pengguna jasa konstruksi untuk memperhatikan kelangsungan usaha BUJK. Asas Kemitraan mengandung pengertian hubungan kerja para pihak yang harmonis, terbuka, bersifat timbal balik, dan sinergis yang melandasi pengaturan di dalam UUJK pada dasarnya telah menjelma dari pengaturan di atas, namun belum memuat suatu norma yang mengatur bagaimana bentuk/pola dan hubungan dari kemitraan sinergis antara usaha yang besar, menengah, dan kecil serta antara usaha yang bersifat umum, spesialis, dan keterampilan tertentu. Pengaturan ini penting karena di dalamnya memuat bagaimana hak dan kewajiban antara usaha BUJK tersebut serta apa yang diperbolehkan atau tidak boleh diantara mereka. Selain pengaturan tersebut, penting juga mengatur peran pemerintah dalam membuat suatu regulasi pengadaan barang dan jasa dalam mengakomodir keberadaan BUJK dalam membentuk hubungan transaksionalnya dilandasi oleh kesetaraan dalam hak dan kewajiban. Formula pengaturan BUJK asing di dalam UUJK dipersamakan dengan BUJK nasional dengan kualifikasi besar, sehingga BUJK belum cukup mampu bersaing dengan BUJK asing, maka pembiaran kondisi seperti ini idak berdasarkan atau tidak mendasarkan pada asas keadilan, asas kemandirian dan asas keseimbangan. Pengaturan BUJK asing secara lebih mendalam justru diatur dalam Peraturan Menteri Pekerjaan Umum Nomor 05/PRT/M/2011. Materi muatan yang diatur dalam Permen tersebut lebih mempunyai nilai fungsi sebagai materi muatan yang seharusnya dimuat dalam undang-undang dalam hal UUJK. Oleh karena itu untuk mendapatkan suatu kepastian hukum dan mencegah adanya conflict of interest, proses pembinaan dalam kerangka penerbitan SBU perlu dilakukan perubahan tata kelola sertifikasi badan usaha dan profesi. Perlunya pengaturan dan penataan terhadap asosiasi dan penyelenggaraan proses sertifikasi yang akuntabel dan penataan asosiasi.

\section{DAFTAR PUSTAKA}

\section{Buku}

Attamimi, A. Hamid S., Peranan Keputusan Presiden Republik Indonesia Dalam Penyelenggaraan Pemerintahan Negara, Suatu Studi Analisis Mengenai Keputusan Presiden Yang Berfungsi Pengaturan Dalam Kurun Waktu Pelita I - Pelita IV (Disertasi), (Jakarta, Fakultas Pascasarjana UI, 1990).

Farida Indrati S, Maria., Ilmu Perundang-undangan: Jenis, Fungsi, dan Materi Muatan, (Jakarta: Kanisius, 2007).

Garner, Bryan A. (Ed.), Black's Law Dictionary $9^{\text {th }}$ Edition, (St. Paul Minnesota, USA: Thomas Reuters, 2010). 
Hartono, C.F.G. Sunaryati, Penelitian Hukum Di Indonesia Pada Akhir Abad Ke-20, (Bandung: Alumni, 2006).

Kartiwan, Iwan, Kamajaya Al Katuuk, Hendra N. Soenardji, Wajah Jasa Konstruksi Indonesia, Tinjauan Keberpihakan, (Jakarta: Gramedia Pustaka Utama, 2010).

Komisi Pengawas Persaingan Usaha, Position Paper KPPU Terhadap Perkembangan Sektor Jasa Konstruksi, (Jakarta: KPPU, tanpa tahun).

Muhammad, Abdulkadir, Hukum dan Penelitian Hukum, (Bandung: Citra Aditya Bakti, 2004).

Soekanto, Soerjono, Pengantar Penelitian Hukum, (Jakarta: UI Press, 1986).

Supranto, J., Metode Penelitian Hukum dan Statistik, (Jakarta: Rineka Cipta, 2003).

Trijono, Rachmat (Ed.), Pola Penelitian dan Pengkajian Hukum Dalam Pembentukan Sistem Hukum Nasional, (Jakarta: Badan Pembinaan Hukum Nasional Kementerian Hukum dan Hak Asasi Manusia RI, 2011).

Tim Penyusun Kamus Pusat Pembinaan dan Pengembangan Bahasa Departemen Pendidikan dan Kebudayaan, Kamus Besar Bahasa Indonesia, (Jakarta: Balai Pustaka, 1990).

Tim Penyusun Buku Konstruksi Indonesia 2011, Konstruksi Indonesia 2011, Penyelenggaraan Infrastruktur Berkelanjutan, Inovasi Investasidan Dukungan Sektor Konstruksi Indonesia, (Jakarta: Kementerian Pekerjaan Umum, 2011).

Wignjosoebroto, Soetandyo, Ragam-ragam Penelitian Hukum. Dalam Irianto, Sulistyowati dan Shidarta (Ed.). Metode Penelitian Hukum Konstelasi dan Refleksi, (Jakarta: Yayasan Pustaka Obor Jakarta, 2011).

\section{Makalah / Artikel / Prosiding / Hasil Penelitian}

Kartasasmita, Agus G., "Pengadaan Barang / Jasa Pemerintah Menurut Pelaku Usaha" (makalah disampaikan pada Seminar Nasional dengan tema "Upaya Perbaikan Sistim Penyelenggaraan Barang / Jasa Pemerintah", diselenggarakan oleh Komisi Pengawas Persaingan Usaha (KPPU) dan Komisi Pemberantasan Korupsi (KPK), di Hotel Nikko Jakarta, 23 Agustus 2006).

Mengantisipasi Dampak Perubahan Regulasi Bidang Jasa Konstruksi (Majalah Tren Konstruksi edisi Juni 2010).

Pranoto, Bambang, "Nasionalisme Konstruksi Indonesia" (makalah), disampaikan pada Civil
Engineering Conference - Unika Soegijapranata di Semarang pada tanggal 17-18 Juni 2005.

Suraji, Akhmad \& Krishna S Pribadi (Ed.), Membangun Struktur Industri Konstruksi Nasional Yang Kokoh, Andal Dan Berdayasaing Serta Memberikan Kesempatan Kepada Para Pelaku Usaha Tumbuh Dan Berkembang Secara Adil Melalui Restrukturisasi Sistem, Diseminasi Hasil Rumusan Seminar Konstruksi Nasional Indonesia I Tahun 2012, diselenggarakan oleh Badan Pembinaan Konstruksi (BP-Konstruksi) Kementerian PU, Lembaga Pengembangan Jasa Konstruksi Nasional (LPJKN), dan GAPENSI).

\section{Internet}

Badan Pembinaan Konstruksi Kementerian Pekerjaan Umum, Glossary Sumber Daya Investasi, http:// pusbinsdi.net/glossary.php?lagi=0, (diakses 10 Juni 2012).

Komisi Pengawas Persaingan Usaha, Persaingan Usaha dan Jasa Konstruksi (Makalah). Sumber: www.kppu.go.id, (diakses 20 Juni 2012).

Muhanda, Dadan, Jasa Konstruksi Masuki Babak Baru, sumber: http://www.lkpp.go.id/v2/beritadetail.php?id=1668785862, (diakses 15 Juli 2012).

Soerono, Agoes S., Pasar Konstruksi Indonesia 70\% Digerogoti Asing, Harian Ekonomi Neraca, 20 Juni 2012, sumber: http://www.neraca. co.id/2012/06/20/pasar-konstruksi-indonesia70-digerogoti-asing/, (diakses 1 Juli 2012).

http://data.worldbank.org/indicator/NE.GDI.FTOT. CD, (diakses tanggal 01 Juli 2012).

http://www.Ipjk.net/grafik-jasa-kontruksi.php, (diakses 05 Juni 2012).

http://www.bisnis.com/articles/jasa-konstruksikontraktor-kecil-butuh-perlindungan, (diakses 14 Juli 2012).

http://www.bisnis.com/articles/jumlah-kontraktorasing-meningkat-pesat, (diakses 15 Juni 2012).

http://www.jasakonstruksi.net/index.php/ frontyard/article/index/asosiasi_bu dan http:// www.jasakonstruksi.net/index.php/frontyard/ article/index/asosiasi_jakon, (diakses 13 Juli 2012).

\section{Peraturan}

Undang-Undang Nomor 5 Tahun 1999 tentang Larangan Praktek Monopoli dan Persaingan Usaha Tidak Sehat (Lembaran Negara Republik 
Indonesia Tahun 1999 Nomor 33, Tambahan Lembaran Negara Republik Indonesia Nomor 3817)

Undang-Undang Nomor 18 Tahun 1999 tentang Jasa Konstruksi (Lembaran Negara Republik Indonesia Tahun 1999 Nomor 54, Tambahan Lembaran Negara Republik Indonesia Nomor 3833)

Undang-Undang No. 12 Tahun 2011 tentang Pembentukan Peraturan Perundang-undangan (Lembaran Negara Republik Indonesia Tahun 2011 Nomor 82, Tambahan Lembaran Negara Republik Indonesia Nomor 5234)

Peraturan Pemerintah Nomor 28 Tahun 2000 tentang Usaha dan Peran Masyarakat Jasa Konstruksi (Lembaran Negara Republik Indonesia Tahun 2000 Nomor 63)

Peraturan Pemerintah Nomor 29 Tahun 2000 tentang Penyelenggaraan Jasa Konstruksi (Lembaran Negara Republik Indonesia Tahun 2000 Nomor 64, Tambahan Lembaran Negara Republik Indonesia Nomor 3956)

Peraturan Pemerintah Nomor 30 Tahun 2000 tentang Penyelenggaraan Pembinaan Jasa Konstruksi (Lembaran Negara Republik Indonesia Tahun 2000 Nomor 65, Tambahan Lembaran Negara Republik Indonesia Nomor 3957)

Peraturan Pemerintah Nomor 4 Tahun 2010 tentang Perubahan atas Peraturan Pemerintah Nomor 28 Tahun 2000 tentang Usaha dan Peran Masyarakat Jasa Konstruksi (Lembaran Negara Republik Indonesia Tahun 2010 Nomor 7, Tambahan Lembaran Negara Republik Indonesia Nomor 5092)
Peraturan Pemerintah Nomor 59 Tahun 2010 tentang Perubahan atas Peraturan Pemerintah Nomor 29 Tahun 2000 tentang Penyelenggaraan Jasa Konstruksi (Lembaran Negara Republik Indonesia Tahun 2010 Nomor 95)

Peraturan Pemerintah Nomor 92 Tahun 2010 tentang Perubahan Kedua atas Peraturan Pemerintah Nomor 28 Tahun 2000 tentang Usaha dan Peran Masyarakat Jasa Konstruksi (Lembaran Negara Republik Indonesia Tahun 2010 Nomor 157)

Peraturan Pemerintah Nomor 4 Tahun 2010 tentang Perubahan Atas Peraturan Pemerintah Nomor 28 Tahun 2000 tentang Usaha dan Peran Masyarakat Jasa Konstruksi

Peraturan Presiden Nomor 5 Tahun 2010 tentang Rencana Pembangunan Jangka Menengah Nasional Tahun 2010 - 2014

Keputusan Dewan Perwakilan Rakyat Indonesia Nomor 08/DPR RI/II/2011-2012 tentang Program Legislasi Nasional Rancangan Undang-Undang Prioritas Tahun 2012

Keputusan Dewan Perwakilan Rakyat Indonesia Nomor 02B/DPR RI/II/2010-2011 tentang Program Legislasi Nasional Rancangan UndangUndang Prioritas Tahun Anggaran 2011

Peraturan Menteri Pekerjaan Umum Nomor 04/ $\mathrm{PRT} / \mathrm{M} / 2011$ tentang Pedoman Persyaratan Pemberian Izin Usaha Jasa Konstruksi Nasional

Peraturan Menteri Pekerjaan Umum Nomor 05/PRT/M/2011 Pedoman Persyaratan Pemberian Izin Perwakilan Badan Usaha Jasa Konstruksi Asing 